\title{
Putrescine oxidase of Micrococcus rubens: primary structure and Escherichia coli
}

\author{
Hiroshi Ishizuka, Sueharu Horinouchi* and Teruhiko BePPU \\ Department of Agricultural Chemistry, Faculty of Agriculture, The University of Tokyo, Bunkyo-ku, Tokyo113, Japan
}

(Received 20 July 1992; revised 23 September 1992; accepted 10 November 1992)

\begin{abstract}
The flavin adenine dinucleotide (FAD)-containing putrescine oxidase of Micrococcus rubens catalyses the oxidative deamination of putrescine. The amino acid sequences of the $\mathrm{NH}_{2}$-termini of the mature enzyme and lysylendopeptidase-generated fragments were determined for preparation of synthetic oligonucleotides as hybridization probes for cloning. A $4.4 \mathrm{~kb}$ BamHI fragment which contained DNA sequences hybridizing to the probes was cloned in pUC19 in Escherichia coli. The nucleotide sequence together with the determined amino acid sequences revealed that this enzyme consists of 480 amino acids $\left(M_{\mathrm{r}} \mathbf{5 2 0 0 0}\right)$ and contains an FAD-binding consensus sequence at its $\mathbf{N H}_{2}$-terminal portion. In front of the transcriptional start point, which is $\mathbf{2 8}$ bases upstream of the initiation codon as determined by primer extension, -35 and -10 sequences similar to typical prokaryotic promoter consensus sequences are present. $E$. coli JM109 containing the putrescine oxidase gene just downstream of the lac promoter in pUC18 produced a large amount of this protein when grown at $37^{\circ} \mathrm{C}$ but in the enzymically inactive form of inclusion bodies. However, cultivation of the recombinant $E$. coli cells at temperatures below $30^{\circ} \mathrm{C}$ led to production of active enzyme ( 20 times as much as produced by the original $M$. rubens strain).
\end{abstract}

\section{Introduction}

The presence of putrescine oxidase in a strain of Micrococcus rubens was first reported by Yamada $e t$ al. $(1965 a, b)$. This enzyme is a flavin adenine dinucleotide (FAD)-containing flavoprotein that catalyses the oxidative deamination of putrescine with the following stoichiometry (Adachi et al., 1966; DeSa, 1972):

$$
\mathrm{NH}_{2}\left(\mathrm{CH}_{2}\right)_{4} \mathrm{NH}_{2}+\mathrm{O}_{2}+\underset{\mathrm{NH}_{2}}{\mathrm{H}_{2} \mathrm{O}}\left(\mathrm{CH}_{2}\right)_{3} \mathrm{CHO}+\mathrm{NH}_{3}+\mathrm{H}_{2} \mathrm{O}_{2}
$$

This enzyme also catalyses the deamination of spermidine as follows, but with a low efficiency:

$$
\begin{aligned}
& \mathrm{NH}_{2}\left(\mathrm{CH}_{2}\right)_{4} \mathrm{NH}\left(\mathrm{CH}_{2}\right)_{3} \mathrm{NH}_{2}+\mathrm{O}_{2}+\mathrm{H}_{2} \mathrm{O} \rightarrow \\
& \qquad \mathrm{NH}_{2}\left(\mathrm{CH}_{2}\right)_{3} \mathrm{CHO}+\mathrm{NH}_{2}\left(\mathrm{CH}_{2}\right)_{3} \mathrm{NH}_{2}+\mathrm{H}_{2} \mathrm{O}_{2}
\end{aligned}
$$

The putrescine oxidase of $M$. rubens differs strikingly from the diamine oxidases of animal (Tabor, 1951; Mondovi et al., 1964) and plant (Mann, 1961) cells in its

\footnotetext{
*Author for correspondence. Tel. 338122111 ext. 5147; fax 33812 0544.

Abbreviations: IPTG, isopropyl $\beta$-D-thiogalactopyranoside; SD, Shine-Dalgarno.

The nucleotide sequence data described in this paper have been submitted to DDBJ, EMBL and GenBank and have been assigned the accession number D12511.
}

substrate and inhibitor specificities. Furthermore, this enzyme, which comprises two identical subunits, contains $1 \mathrm{~mol}$ of FAD per mol of enzyme, whereas several other FAD-containing oxidases, such as glucose oxidase (Swoboda \& Massay, 1965), D-amino acid oxidase (Massay et al., 1961) and L-amino acid oxidase (Wellner \& Meister, 1961), contain two FAD moieties per mol of enzyme.

In addition to its unique enzymic features, the putrescine oxidase of $M$.rubens is now used as a diagnostic enzyme for measurement of polyamines. Because patients with histologically diagnosed tumours and leukaemias have a high content of polyamines (Russell et al., 1971), the amount of polyamines is a useful marker of cancer (Takami et al., 1979).

Because of the enzymically interesting features and diagnostic importance of the putrescine oxidase of $M$.rubens, we intended to determine the primary structure of the enzyme by means of cloning and nucleotide sequencing of the putrescine oxidase (puo) gene. At the same time, DNA manipulations of the cloned puo gene with Escherichia coli host-vector systems were expected to improve enzyme production. This report describes the cloning, nucleotide sequence (together with the derived amino acid sequence) and transcriptional analysis of the puo gene. E. coli JM109 containing a recombinant plasmid produced a large 
amount of enzymically active putrescine oxidase, when cultured at lower temperatures in order to avoid formation of inclusion bodies.

\section{Methods}

Bacterial strains and plasmids. M. rubens IFO 3768, originally reported by Yamada et al. $(1965 b)$, was obtained from Amano Pharmaceutical Co., Nagoya. Escherichia coli JM109 [ $\Delta$ (lac-pro) thi-1 endAl gyrA96 hsdR17 relA1 recAl $\mathrm{F}^{\prime}$ traD36 proAB lacl lacZDM15] (Yanisch-Perron et al., 1985) was used as the host for manipulation and expression of the cloned gene and for phage M13 propagation. The ampicillin-resistance plasmids pUC18 and pUC19 (Yanisch-Perron et al., 1985) containing the E. coli lac promoter were purchased from Takara Shuzo Co., Kyoto. Phage M13 derivatives, M13mp18 and M13mp19, were obtained from Amersham.

Media. M. rubens was cultured at $30^{\circ} \mathrm{C}$ in medium containing $\left(\mathrm{g}^{-1}\right)$ : polypeptone (Daigo Eiyo), 5 ; yeast extract (Difco), 5 ; glucose, $1 ; \mathrm{NaCl}, 1$; adjusted to $\mathrm{pH} 7.0 .2 \times$ YT medium (Messing, 1983) and Lbroth (Miller, 1972) were used for E. coli.

Enzymes and chemicals. Restriction endonucleases, T4 DNA ligase, T4 polynucleotide kinase, Klenow fragment of DNA polymerase I, S1 nuclease and ExoIII nuclease were purchased either from Takara Shuzo Co. or Boehringer-Mannheim. $\left[\alpha^{-32} \mathrm{P}\right] \mathrm{dATP}\left[3000 \mathrm{Ci} \mathrm{mmol}^{-1}\right.$ (111 TBq mmol $\left.\left.{ }^{-1}\right)\right]$ and $\left[\gamma_{-}^{32}\right.$ P]ATP $\left[>5000 \mathrm{Ci} \mathrm{mmol}^{-1}(185 \mathrm{Tbq}\right.$ $\left.\mathrm{mmol}^{-1}\right)$ ] were from Amersham. Lysyl endopeptidase and peroxidase were purchased from Wako Pure Chemicals, Osaka. Putrescine dihydrochloride was from Nakarai Chemical Co., Tokyo.

Purification of putrescine oxidase and determination of its amino acid sequence. Putrescine oxidase from M. rubens IFO 3768 was purified essentially according to the method of Adachi et al. (1966). Briefly, a crude extract was obtained by sonication of cells of $M$. rubens. Proteins were precipitated with ammonium sulphate (35-70\% saturation). Putrescine oxidase was further purified by successive chromatography on DEAE-cellulose, aminooctyl-Sepharose and aminododecylSepharose. The final enzyme preparation gave a main band (about $99 \%$ purity) with an additional faint band on SDS-PAGE. For $\mathrm{NH}_{2}-$ terminal amino acid sequence determination by automated Edman degradation, an Applied Biosystems 470A sequencer was used. For determination of internal amino acid sequences, the enzyme sample $(2 \mathrm{nmol})$ was digested with $170 \mathrm{pmol}$ of lysyl endopeptidase by incubation at $32{ }^{\circ} \mathrm{C}$ for $8 \mathrm{~h}$ in $20 \mathrm{~mm}$-Tris/ $\mathrm{HCl}$ (pH 9.0) containing 3.5 M-urea. The lysyl-endopeptidase-digested mixture was applied to an HPLC apparatus equipped with a YMC-PACK A-312 ODS column $(6.0 \times 150 \mathrm{~mm})$ and eluted with a linear gradient of acetonitrile $(5-95 \%)$ at a flow rate of $1.0 \mathrm{ml} \mathrm{min}^{-1}$. Several peaks were chosen for amino acid sequence analysis using the automated sequencer.

Synthesis of oligonucleotide probes. Three oligonucleotides, 26-29 nucleotides in length, which corresponded to partial amino acid sequences of putrescine oxidase, were synthesized by the phosphoamidite method on a Milligen Cyclone Plus DNA synthesizer. The oligonucleotides were purified by $15 \%(\mathrm{w} / \mathrm{v})$ polyacrylamide gel electrophoresis, labelled at their $5^{\prime}$ ends with T4 polynucleotide kinase and $\left[\gamma-{ }^{32} \mathrm{P}\right] \mathrm{ATP}$, and used as hybridization probes.

Oligonucleotide screening of the putrescine oxidase gene. General recombinant DNA techniques were as described by Maniatis et al. (1982). Chromosomal DNA was prepared after lysis of cells with lysozyme, using the procedure described by Saito \& Miura (1963). Southern hybridization between BamHI-digested chromosomal DNA and the above three probes was done according to the method of Southern (1975) with the following modifications. Pre-hybridization in
$6 \times \mathrm{NET}(1 \times \mathrm{NET}$ is $0 \cdot 15 \mathrm{M}-\mathrm{NaCl}, 1 \mathrm{~mm}$-EDTA, $15 \mathrm{~mm}$ Tris $/ \mathrm{HCl}$, pH 7.5) containing $0.5 \%$ Nonidet P-40, $1 \times$ Denhardt's solution and $50 \mu \mathrm{g}$ salmon sperm DNA ml-1 was carried out at $60^{\circ} \mathrm{C}$ for $2 \mathrm{~h}$. Hybridization was then done with the ${ }^{32} \mathrm{P}$-labelled probes at $42^{\circ} \mathrm{C}$ for $16 \mathrm{~h}$ in the same buffer. The nitrocellulose filters were washed three times in $2 \times \mathrm{SSC}(1 \times \mathrm{SSC}$ is $0.15 \mathrm{M}-\mathrm{NaCl}, 0.015 \mathrm{M}$-sodium citrate $)$ containing $0.1 \%$ SDS. A distinct $4.4 \mathrm{~kb}$ band hybridizing to three probes was detected. From an agarose gel slice $(10 \times 3 \times 2 \mathrm{~mm})$, which contained Bam HI fragments in the size range $4 \cdot 2-4.5 \mathrm{~kb}$, DNA was extracted by the sodium perchlorate method (Chen \& Thomas, 1980) and ligated with T4 DNA ligase to BamHI-digested pUC19. The ligated mixture was then introduced by transformation into $E$. coli JM109 and ampicillin-resistant transformants were selected on $2 \times$ YT medium containing $50 \mu \mathrm{g}$ ampicillin $\mathrm{ml}^{-1}$. Colony hybridization (Grunstein \& Hogness, 1975) with the ${ }^{32} \mathrm{P}$-labelled probe designed for the $\mathrm{NH}_{2}$-terminal amino acid sequence was used to identify positive colonies, under the same conditions as for the above Southern hybridization. Plasmid DNA was prepared from the positive colonies by $\mathrm{CsCl}$ /ethidium bromide ultracentrifugation. Restriction endonuclease analysis together with Southern hybridization experiments with the probes indicated the location of the putrescine oxidase gene.

Construction of expression plasmids. Starting with the DNA fragment originally cloned, we constructed the following plasmids (see Fig. 1). For construction of pPUO2, pPUO3 and pPUO4, the $3.3 \mathrm{~kb}$ BamHI-StuI-1 fragment containing puo was first cloned between the BamHI and HincII sites of pUC18. The recombinant plasmid was then cut with KpnI plus BamHI, and the BamHI end trimmed with exonuclease III and S1 nuclease. The trimmed ends were filled-in with Klenow fragment and recircularized with T4 DNA ligase. The nucleotide sequences of each of the junctions were then determined by the dideoxynucleotide method.

Nucleotide sequencing. For nucleotide sequencing, specific restriction fragments covering the putrescine oxidase gene were cloned on appropriate M13 vectors and sequenced by the chain-terminating dideoxynucleotide method (Sanger et al., 1977). The whole nucleotide sequence was determined in both orientations, and all the restriction sites used for cloning into M13 phages were verified by determination as part of an overlapping sequence.

Primer extension. Total cellular RNA was prepared from $M$. rubens grown to the late exponential phase in medium with or without $90 \mu \mathrm{g}$ putrescine $\mathrm{ml}^{-1}$, essentially according to the method described previously (Horinouchi et al., 1987). A 25-mer oligonucleotide, 5'ACGAGCGTGCGGGCGGCCATGAGCC-3', complementary to a sequence in the puo gene (nucleotides 588 to 612 in Fig. 2), was synthesized on the DNA synthesizer and 5 -endlabelled with T4 polynucleotide kinase and $\left[\gamma_{-}{ }^{32} \mathrm{P}\right] \mathrm{ATP}$. About $20 \mu \mathrm{g}$ of the total cellular RNA and 20 ng of 5 '-endlabelled oligonucleotide primer were heated at $80^{\circ} \mathrm{C}$ for $10 \mathrm{~min}$ and then at $42^{\circ} \mathrm{C}$ for $5 \mathrm{~h}$ in $50 \mu \mathrm{l} 20 \mathrm{~mm}$-Tris/ $\mathrm{HCl}$ (pH 8.3), $200 \mathrm{~mm}-\mathrm{KCl}$. Reverse transcription with 10 units of avian myeloblastosis virus reverse transcriptase was carried out at $42^{\circ} \mathrm{C}$ for $1 \mathrm{~h}$ in $100 \mu \mathrm{l} 100 \mathrm{~mm}$-Tris/ $\mathrm{HCl}$ (pH 8.3), $100 \mathrm{~mm}-\mathrm{KCl}, 10 \mathrm{~mm}-\mathrm{MgCl}_{2}$, $10 \mathrm{~mm}$-dithiothreitol, $0.5 \mathrm{~mm}$ each of deoxyribonucleotides and $50 \mu \mathrm{g}$ actinomycin $\mathrm{D} \mathrm{ml}^{-1}$. The extended product was analysed by denaturing $8 \%$ polyacrylamide gel electrophoresis. Dideoxynucleotide sequencing reactions primed from the oligonucleotide were electrophoresed in neighbouring lanes.

Preparation of crude-extract from an E. coli transformant containing the puo gene. E. coli JM109 containing recombinant plasmids was grown at $37^{\circ} \mathrm{C}$ overnight in $2 \times \mathrm{YT}$ medium containing $50 \mu \mathrm{g}$ ampicillin $\mathrm{ml}^{-1}$, and $0 \cdot 1 \mathrm{ml}$ of the culture was transferred to $10 \mathrm{ml}$ of L-broth containing ampicillin. After a $4 \mathrm{~h}$ incubation at $37^{\circ} \mathrm{C}$, isopropyl $\beta$-Dthiogalactopyranoside (IPTG) was added at a final concentration of 
$2 \mathrm{mM}$ to induce the lac promoter and cultivation was continued at $37^{\circ} \mathrm{C}$. Because the cells grown in this way produced enzymically inactive putrescine oxidase, probably as inclusion bodies, we changed the temperature for growing the cells. After a $3 \mathrm{~h}$ incubation of the overnight culture in fresh L-broth at $37^{\circ} \mathrm{C}$, the cultivation was continued at two different temperatures, $26.5^{\circ} \mathrm{C}$ and $30^{\circ} \mathrm{C}$, for another $1 \mathrm{~h}$. IPTG was then added and the cultivation was continued at the respective temperatures. The cells from $10 \mathrm{ml}$ of culture were harvested by centrifugation and washed once with $10 \mathrm{mM}-\mathrm{KH}_{2} \mathrm{PO}_{4} / \mathrm{NaOH}$ buffer (pH 7.0) containing $50 \mathrm{~mm}-\mathrm{NaCl}$. The washed cells were suspended in $2 \mathrm{ml}$ of the same buffer and disrupted by sonication. The sonicate was then centrifuged at $15000 \mathrm{~g}$ for $30 \mathrm{~min}$. The supernatant and the pellet were used for the putrescine oxidase assays. SDS-PAGE was performed according to the method of Laemmli (1970).

Assay of putrescine oxidase. The enzyme was assayed by colorimetric determination of the amount of $\mathrm{H}_{2} \mathrm{O}_{2}$ produced by use of peroxidase, 4-aminoantipyrine and phenol as the colour-producing reagents. The standard assay mixture in a total volume of $3.1 \mathrm{ml}$ contained $0.2 \mathrm{M}$ $\mathrm{KH}_{2} \mathrm{PO}_{4} / \mathrm{NaOH} \quad(\mathrm{pH} 8.0), 3.23$ mM-putrescine dihydrochloride, $0.032 \%(\mathrm{w} / \mathrm{v})$ phenol, $0.2 \mathrm{mg}$ 4-aminoantipyrine, 8 units peroxidase and $0.1 \mathrm{ml}$ of enzyme solution. The reaction was started by addition of enzyme solution after the reagents and the substrate had been preincubated at $37^{\circ} \mathrm{C}$ for $3 \mathrm{~min}$. The reaction was followed at $37^{\circ} \mathrm{C}$ by measuring the change in $A_{505}$. The molar absorbance index of $6.25 \times 10^{3} \mathrm{M}^{-1} \mathrm{~cm}^{-1}$ for the dye formed under these conditions was used for calculations. One unit of enzyme activity was defined as the amount of enzyme that catalysed the formation of $1 \mathrm{nmol} \mathrm{H}_{2} \mathrm{O}_{2} \mathrm{~min}^{-1}$. Protein concentration was measured with the Bio-Rad protein assay kit using bovine serum albumin as the standard.

\section{Results and Discussion}

\section{Cloning of the puo gene}

Putrescine oxidase was purified from $M$. rubens IFO 3768 to near homogeneity by SDS-PAGE. An apparent $M_{\mathrm{r}}$ of 50000 , was calculated, in agreement with that reported by Adachi et al. (1966) and DeSa (1972). The $\mathrm{NH}_{2}-$ terminal amino acid sequence along with the partial amino acid sequences of lysyl-endopeptidase-generated fragments were determined to prepare hybridization probes for cloning of the puo gene. For the $\mathrm{NH}_{2}$-terminal sequence, Thr-Asp-Glu-Arg-Thr-Leu-Gly-Ser-Glu-ThrAla-Ile-Glu-Arg-Asp-Val-Val-Val-X-Gly-Ala-Gly-ProAla-Gly (where $\mathrm{X}$ stands for an amino acid which was not unambiguously determined), a 26-mer nucleotide sequence corresponding to $\mathrm{Thr}-5$ to Glu-13, 5'-ACICTIGGITCIGAIACIGCIATIGA-3' (probe I) was synthesized. Inosine was used for all the bases corresponding to the third codon positions. The two internal amino acid sequences determined with lysyl-endopeptidase-generated fragments and the corresponding nucleotides were Asp-Val-Val-Val-Ala-Val-Pro-Pro-Asn-Leu-Tyr-Ser-ArgIle-Ser-Phe-Glu-Pro-Pro-Leu [from Asp-1 to Leu-10, 5'-AGITTIGGIGGIACIGCIACIACIACITC-3' (probe II)] and Val-His-Ala-Val-Tyr-Glu-Thr-Pro-Phe-TrpArg-Asp-Lys [from Tyr-5 to Lys-13, 5'-TTGTCNCGCCAGAANGGNGTCTCGTA-3' (probe III); where
$\mathrm{N}$ stands for $\mathrm{G}, \mathrm{A}, \mathrm{T}$ and $\mathrm{C}]$. Probes II and III were from the non-coding strand.

Southern blot hybridization between BamHI-digested chromosomal DNA of $M$. rubens and the above three synthetic nucleotides gave a common positive band of about $4.4 \mathrm{~kb}$. We used probe I for the initial cloning of the puo gene. The BamHI-digested fragments of $4 \cdot 2$ to $4.5 \mathrm{~kb}$ were purified by agarose gel electrophoresis, ligated with BamHI-digested pUC19 DNA, and introduced by transformation into $E$. coli JM109. About 500 ampicillin-resistant transformants which did not turn blue on an X-Gal plate were screened by colony hybridization with probe I. Positive candidates were then screened by a second colony hybridization with probes II and III, and five colonies showing positive hybridization were selected. Restriction mapping of the plasmid DNA prepared from the five colonies showed that all contained the same $4.4 \mathrm{~kb}$ fragment at the BamHI site of pUC19. We chose one of these plasmids and used it for further studies. Fig. 1 shows the restriction map of the plasmid, named pPUO1. Southern hybridization experiments with purified pPUO1 DNA indicated that probes I, II and III hybridized to the SacI-1-SalI-1 fragment, Pst I-3-Pst $\mathrm{I}-4$ fragment and PstI-4-SalI-2 fragment, respectively.

\section{Nucleotide sequence of the puo gene}

On the basis of the results described above, we determined the nucleotide sequence of the Pst I-1-SmaI4 fragment by the chain-terminating dideoxynucleotide method. Fig. 2 shows the 2386 bp nucleotide sequence and the amino acid sequence derived therefrom. The open reading frame of 481 amino acids with a calculated $M_{\mathrm{r}}$ of 52000, which started with GTG (methionine) and terminated with a TGA codon, was found to code for amino acid sequences corresponding precisely to those determined by protein sequencing using the purified putrescine oxidase. Comparison of the $\mathrm{NH}_{2}$-terminal amino acid sequence determined with the mature enzyme and that deduced from the nucleotide sequence suggested that the $\mathrm{NH}_{2}$-terminal methionine was processed after translation. The reading frame is preceded by a nucleotide sequence, AAGGAG, which we assume serves as a ribosome-binding sequence (Shine \& Dalgarno, 1974).

The overall $\mathrm{G}+\mathrm{C}$ composition of the $2386 \mathrm{bp}$ is $72.8 \%$ and those of positions 1,2 , and 3 of the codons are $71.4 \%, 47.8 \%$ and $99.0 \%$, respectively. The high $\mathrm{G}+\mathrm{C}$ content is reflected preferentially at the third codon position. The $\mathrm{G}+\mathrm{C}$ content of the second codon position is considerably lower. Such a codon usage pattern is characteristic for genes with a high $\mathrm{G}+\mathrm{C}$ content from various bacteria (Bibb et al., 1984). 

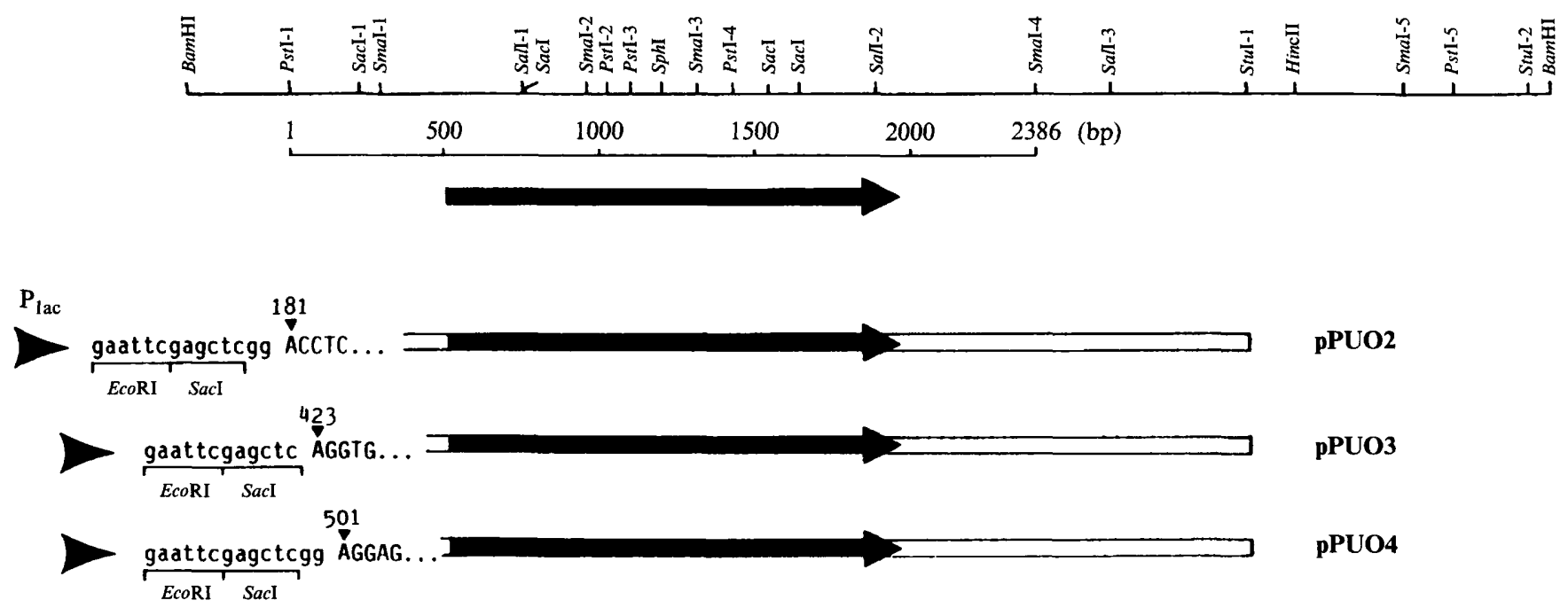

Fig. 1. Restriction endonuclease map of the $4.4 \mathrm{~kb}$ DNA fragment on pPUO1 (top) and the nucleotide sequences of the junctions between the lac promoter and the puo gene (bottom). The arrows indicate the direction and extent of the region coding for putrescine oxidase. The nucleotide sequences in lower-case letters are derived from the polylinker present downstream from the lac promoter $\left(\mathbf{P}_{\text {lac }}\right)$, and the $5^{\prime}$-flanking sequences of puo are shown together with the nucleotide number (Fig. 2). Due to the enzymic properties of S1 nuclease (Green \& Roeder, 1980), the KpnI end was also found to be trimmed with S1 nuclease.

As mentioned above, the putrescine oxidase of $M$. rubens contains $1 \mathrm{~mol}$ of FAD per mol of enzyme. We therefore searched for a consensus sequence for nucleotide-binding domains, called the 'fingerprint' region, of many NAD-dependent dehydrogenases and FAD-containing oxidases (Scrutton et al., 1990; Wierenga et al., 1985). The search revealed the presence of Gly-X-Gly-(X) $)_{2}$-Gly-(X) $)_{10}$-Gly (where X stands for any amino acid) at the $\mathrm{NH}_{2}$-terminal region of this protein, as shown in Fig. 2.

\section{Transcriptional analysis of the puo gene by primer extension}

Primer extension was used for high resolution mapping of the 5'-end of the puo mRNA (Fig. 3). Primer extensions using RNAs from cells grown in the presence and absence of putrescine identified the same nucleotide at the $5^{\prime}$-end of puo mRNA. This position is $28 \mathrm{bp}$ upstream of the start codon for puo (Fig. 2). That almost the same signal intensity was observed with RNAs from cells grown in the presence and absence of putrescine suggested that putrescine exerted no transcriptional stimulation on puo. This is in agreement with the observation that the enzyme yield was not enhanced in the presence of putrescine in the medium.

There are two hexameric sequences ( $5^{\prime}$-TTGACG- $3^{\prime}$ for -35 and $5^{\prime}$-TTTAAT-3' for -10 , with a $18 \mathrm{bp}$ space) upstream of the transcriptional start point. These show great similarity to consensus sequences (5'TTGACA-3' for -35 and $5^{\prime}$-TATAAT $-3^{\prime}$ for -35 , with a $17 \mathrm{bp}$ space) for other prokaryotic promoters (Rosenberg \& Court, 1979).

\section{Expression of the puo gene in E. coli}

For efficient production of the putrescine oxidase in E. coli, we shortened the distance between the lac promoter on pUC18 and the translational start codon for puo by digestion of the 5 -flanking region of puo with exonuclease III (see Methods). We chose three plasmids constructed in this way, and determined by nucleotide sequencing the $5^{\prime}$-flanking ends of the puo gene linked to the KpnI site of pUC18 (Fig. 1). Plasmid pPUO2 contained the DNA fragment from nucleotide position 181 to the StuI site (Fig. 1) under the control of the lac promoter on pUC18. Similarly, pPUO3 and pPUO4 contained the DNA fragments from nucleotide positions 423 and 501 to the $S t u I$ site, respectively.

E. coli JM109 containing these plasmids was cultured at $37^{\circ} \mathrm{C}$ and the lac promoter was induced by IPTG. Contrary to our expectation, very little putrescine oxidase activity was detected in the soluble or precipitate fraction prepared from each of the $E$. coli transformants. However, SDS-PAGE analyses showed that the precipitates of the sonicated cells, but not the soluble fractions, contained a protein of $M_{\mathrm{r}} 50000$ in large amounts, only when the lac promoter was induced by IPTG. The banding pattern on SDS-PAGE of the insoluble fraction prepared from E. coli JM109 containing pPUO4 is shown in Fig. 4. Plasmid pPUO4 directed the synthesis of the largest amount of the $M_{\mathrm{r}}$ 


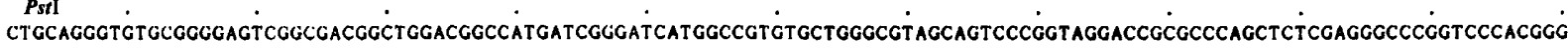

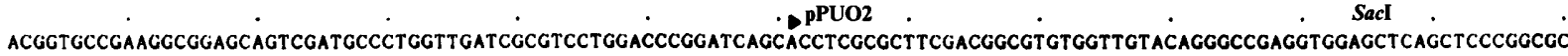

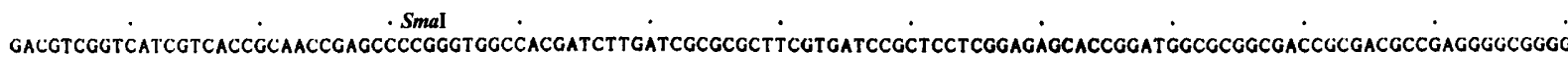

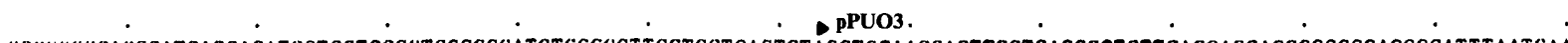
CCGGCGGGAGCCATGAGCAGATCCTCCTGCGGTCGGGGCATGTGGCGCTTCCTCCTGAGTCTAGGTGCAACGAGTTGGTGACGGCTCTIGACGAGCACGGGCCGGAGCCCATTTAATGAA

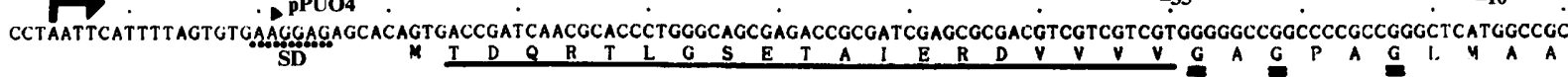
CCGCACGCTCGTGGCCGCCGGGCGGACCGTGGCGGTCCTCGAGGCCCGCGACCGCGTGGGCGGGCGCACCTGGTCGAAGACCGTGGACGGCGCGTTCCTGGAGATCGGCGGGCAGTGGAT


- Sall SacI CTCCCCCGACCAGACCGAGCTGCTGGCGTTGGTCGACGAGCTCGGCCTGGAGACCTACCAGCGCTACCGCGAGGGCGAGTCCGTCTACCTGGCGCCGGACGGGACCCGCCACACCTACAC $S$
$P$

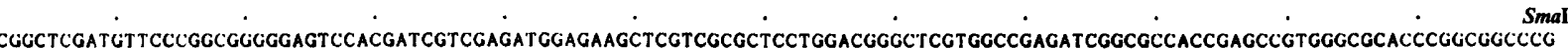
G S M

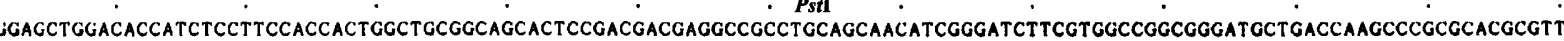
E L L D T I S S F H H W L PstI SphI CTCCGTGCTGCAGGCCGTGCTCATGGCCGCCTCCGCCGGGTCCTTCTCGAACCTCGTGGACGAGGACTTCATCCTCGACCGGCGCGTGGTCGGCGGCATGCAGTCCGTCTCGGAGACCAT


SmaI .



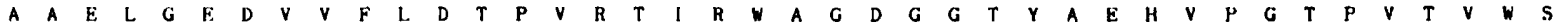
- PstI .

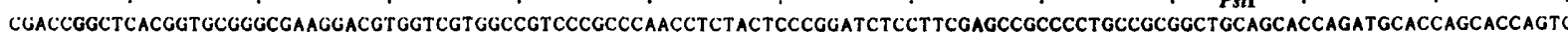

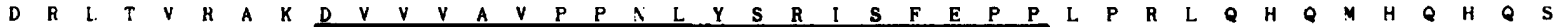
SacI

GCTGGGCCTCGTGATCAAGGTGCACGCCGTCTACGAGACGCCCTTCTGGCGGGACAAGGGCCTCTCCGGCACCGGCTTCGGCGCCCACGAGCTCTCCCAGGAGGTCTACGACAACACCAA

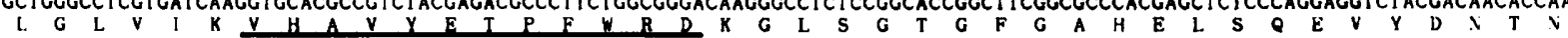
SacI

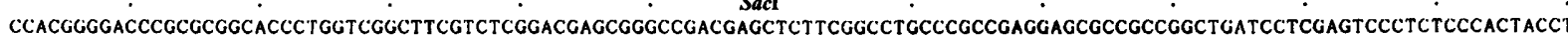

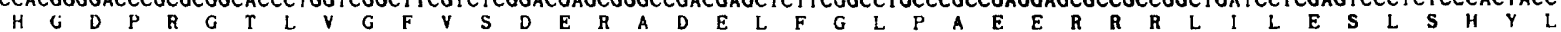




SaI CCAGCGCACCCCGGTGGGCCCGATCCGCTGGGCCTGCTCCGACCTCGCGGCCGAGGGCTACCAGCACGTCGACGGCGCCCTGCGGCAGGGCCGGCTCGCCGCGGCCGAGGTCCTCGGCGC


CGGCTCGCTGACGGGCGCGGAGCGATGACCACCGCCGGGGTGCGCGCTACGTGGTCGGCTACAGCGGCGACCGGCGCAGCCGGGACGCCGTGCGGCTGGGCAGTCGCGCTCGCGCGCGA G S I. T G A E R *

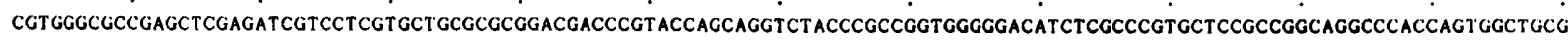

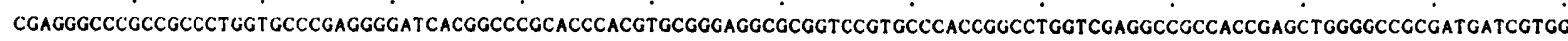
TCGGCGCCGGGACGGGCGGCGGCCGCTTCACCCTGGGTTCCGTGGTGAACGCCTGCTGCACAGCTCGCCGGTCCCCGTGGCGCTCGCCCCGCGCCGGTATCCCGGG

Fig. 2. Nucleotide and deduced amino acid sequences of the putrescine oxidase gene. The underlined amino acid sequences were determined directly from the mature putrescine oxidase purified from $M$. rubens. Four Gly residues in the NAD- and FAD-binding consensus sequence, Gly-X-Gly- $(\mathrm{X})_{2}-\mathrm{Gly}-(\mathrm{X})_{10}$-Gly, are indicated by double underlines. The bent arrow at nucleotide position 484 indicates the transcriptional start point, as determined by primer extension (see Fig. 3). The -35 and -10 sequences with strong similarity to prokaryotic consensus sequences are also shown. SD indicates a possible ribosome-binding sequence. The $5^{\prime}$-flanking ends of the puo gene on plasmids pPUO2, pPUO3 and pPUO4 are shown by triangles, and these ends are connected to the lac promoter on pUC18 (see Fig. 1).

50000 protein, and pPUO3 and pPUO2 directed the synthesis of smaller and similar amounts of the protein. These findings suggested that the putrescine oxidase was produced in an enzymically inactive form, probably as inclusion bodies.

We next cultured the E. coli transformants at lower temperatures to avoid the formation of possible inclusion bodies, because Schein \& Noteborn (1988) observed that $E$. coli cells grown at a lower temperature produced significant amounts of recombinant proteins in a soluble form. When cultured at $26.5^{\circ} \mathrm{C}$ and $30^{\circ} \mathrm{C}$ in the presence of IPTG, the $E$. coli transformants produced a protein of $M_{\mathrm{r}} 50000$ in the soluble fractions, as determined by SDSPAGE (Fig. 4). Almost none of the protein was detected 


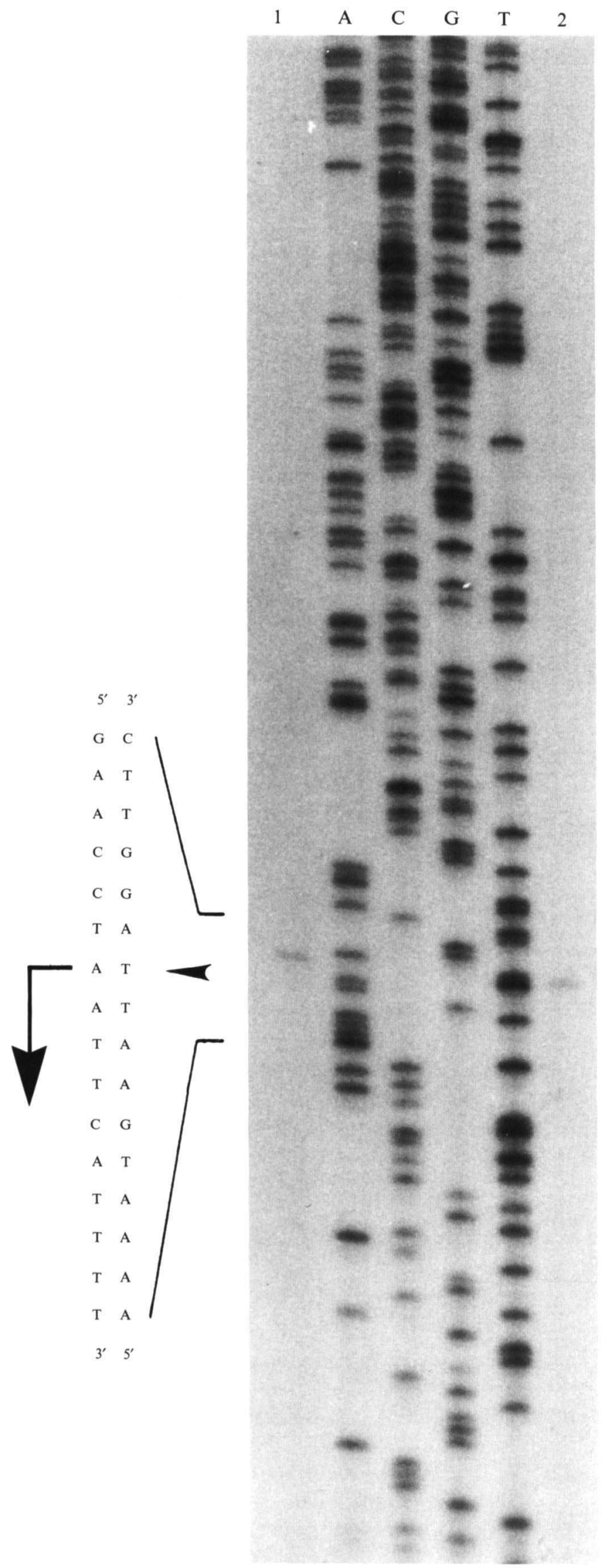

in the precipitate fractions. Plasmid pPUO4 directed the synthesis of the largest amount of the protein at both $26.5^{\circ} \mathrm{C}$ and $30^{\circ} \mathrm{C}$. Consistent with these observation, the soluble fractions prepared from the recombinant $E$. coli cells contained putrescine oxidase activities (Fig. 5). When E. coli JM109 containing pPUO4 was cultured at $30^{\circ} \mathrm{C}$, it produced 1.3 units $\left(\mathrm{ml}\right.$ broth) ${ }^{-1}$, which is 20 times as much putrescine oxidase as produced by the original M. rubens strain.

Why does pPUO4 direct higher expression levels? The puo genes in pPUO2 and pPUO3 appear to utilize the native Shine-Dalgarno (SD) sequence (AAGGAG) which has a suboptimal spacing of only six nucleotides from the GTG start codon. Plasmid pPUO4 fortuitously appears to have acquired a slightly different SD sequence (GGAGG), resulting in a more optimal spacing of eight nucleotides. Since the spacing between the SD sequence and the translational start codon is known to affect the expression of a gene (Shepard et al., 1982; Kawaguchi et al., 1986), this may explain the difference in the level of expression of puo. An additional explanation is that the stability of the mRNA from each of the constructions differs in some way.

Cultivation of the recombinant $E$. coli cells at lower temperatures appears to prevent the formation of inclusion bodies. We have recently found that the cultivation at $26.5^{\circ} \mathrm{C}$ of $E$. coli containing the nitrite reductase gene of Alcaligenes faecalis under the control of the lac promoter leads to production of the enzymically active protein in a large amount (our unpublished observation). Like the case of the putrescine oxidase in the present study, as well as that of human interferon- $\alpha 2$ (Schein \& Noteborn, 1988), E. coli cells grown at $37^{\circ} \mathrm{C}$ do not produce the enzymically active nitrite reductase. The formation of inclusion bodies in recombinant E.coli cells is a serious problem in producing proteins in their active conformation, and these observations suggest that cultivation of recombinant $E$. coli cells at lower temperatures, i.e. at slower growth rates, is a solution to this problem, at least, in some cases. The slower rate of production of proteins, due to a slower rate of growth, may prevent the molecules from aggregating together in some way.

\section{Concluding remarks}

By use of recombinant DNA techniques, the primary structure of the putrescine oxidase from $M$. rubens has

Fig. 3. Determination of the 5 -end of the puo transcript by primer extension analysis. Primer extension reactions using the RNAs from cells grown in the presence (lane 1) and absence (lane 2) of putrescine were analysed against a DNA sequence ladder. 


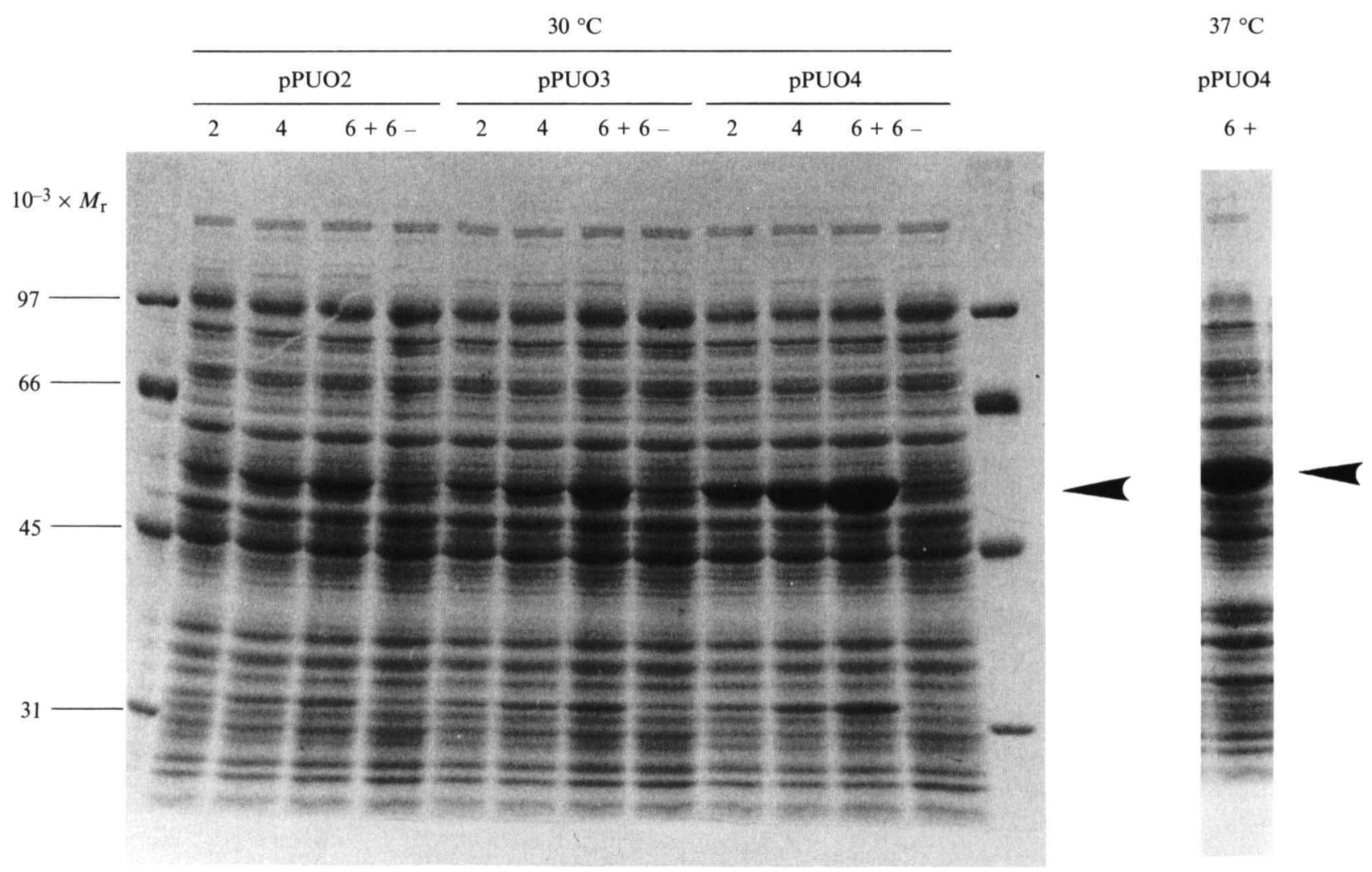

Fig. 4. SDS-PAGE of soluble fractions prepared from E. coli JM109 containing recombinant plasmids. $E$. coli cells containing pPUO2, pPUO3 or pPUO4 were grown at $30^{\circ} \mathrm{C}$ and the lac promoter was induced by addition of IPTG. The cells were harvested at intervals and the soluble fractions were prepared as described in Methods. The numbers on lanes indicate the time (h) after IPTG addition. As negative controls, the soluble fractions similarly prepared from cells grown for $6 \mathrm{~h}$ in the absence of IPTG (6-) are also shown. Putrescine oxidase produced in response to IPTG is indicated by an arrowhead. The pellet fraction prepared from E. coli JM109 containing pPUO4 and grown at $37^{\circ} \mathrm{C}$ is also shown. $M_{\mathrm{r}}$ standards used are phosphorylase $b(97000)$, bovine serum albumin (66000), ovalbumin (45000) and carbonic anhydrase (31000).

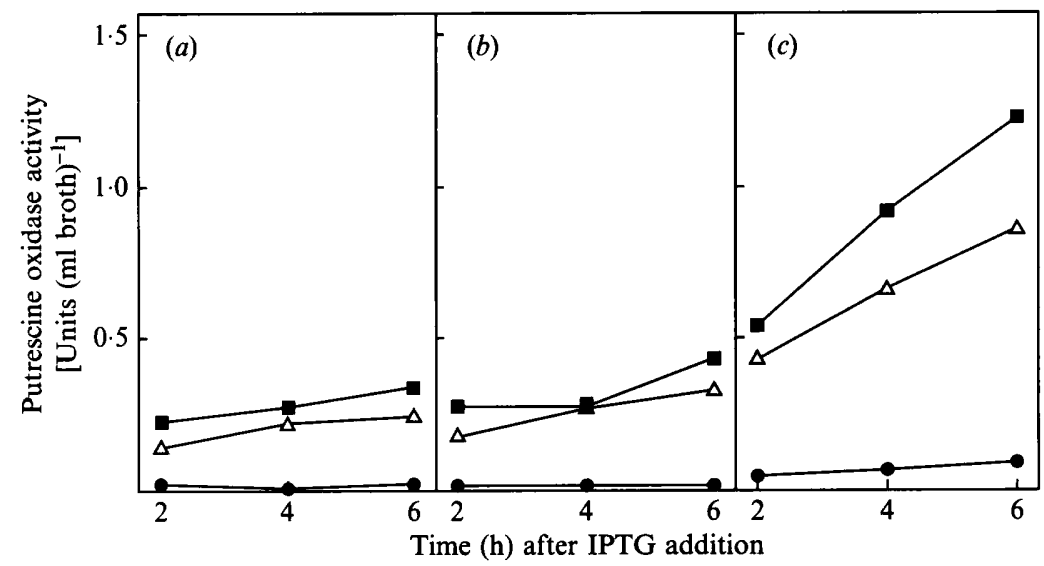

Fig. 5. Production of putrescine oxidase by $E$. coli JM109 containing recombinant plasmids. $E$. coli cells containing pPUO2 (a), pPUO3 (b) or pPUO4 (c) were grown at three different temperatures $\left(\mathbf{G}, 30^{\circ} \mathrm{C} ; \triangle, 26.5^{\circ} \mathrm{C} ; 0,37^{\circ} \mathrm{C}\right)$ in the presence of IPTG. The cells were harvested at intervals and putrescine oxidase activities in the soluble fractions were assayed. 
been determined. This is the first report describing structural information on this type of gene and enzyme. Since protein engineering using the cloned puo gene by means of site-directed mutagenesis is now possible, the present work is a useful step to study further the putrescine oxidase as a unique enzyme among the known flavoprotein oxidases, in that it contains only one FAD moiety per molecule. It is now possible to overproduce the putrescine oxidase enzyme for this purpose. The improvement in enzyme yield is also beneficial in supplying this diagnostically important enzyme for measurement of polyamines. This work represents another example of the use of low temperature to prevent the formation of inclusion bodies when heterologous proteins are expressed in recombinant $E$. coli cells.

\section{References}

Adachi, O., Yamada, H. \& Ogata, K. (1966). Purification and properties of putrescine oxidase of Micrococcus rubens. Agricultural and Biological Chemistry 30, 1202-1210.

Bibb, M. J., Findlay, P. R. \& Johnson, M. W. (1984). The relationship between base composition and codon usage in bacterial genes and its use for the simple and reliable identification of protein-coding sequences. Gene 30, 157-166.

Chen, C. W. \& Thomas, C. A., JR (1980). Recovery of DNA segments from agarose gel. Analytical Biochemistry 101, 339-341.

DeSA, R. J. (1972). Putrescine oxidase from Micrococcus rubens: purification and properties of the enzyme. Journal of Biological Chemistry 247, 5527-5534.

GREen, M. R. \& RoEDER, R. G. (1980). Definition of a novel promoter for the major adenovirus-associated virus mRNA. Cell 22, 231-242.

GrunsteIn, M. \& Hogness, D. S. (1975). Colony hybridization: a method for the isolation of cloned DNAs that contain a specific gene. Proceedings of the National Academy of Sciences of the United States of America 72, 3961-3965.

Horinouchi, S., Furuya, K., Nishiyama, M., Suzuki, H. \& Beppu, T. (1987). Nucleotide sequence of the streptothricin acetyltransferase gene from Streptomyces lavendulae and its expression in heterologous hosts. Journal of Bacteriology 169, 1929-1937.

Kawaguchi, Y., Yanagida, N., Uozumi, T. \& Beppu, T. (1986). Improved direct expression of prochymosin cDNA through changing the SD-ATG codon length. Agricultural and Biological Chemistry 50, 499-500.

LAEMMLI, U. K. (1970). Cleavage of structural proteins during the assembly of the head of bacteriophage T4. Nature, London 227, 680-685.

Maniatis, T., Fritsch, E. F. \& Sambrook, J. (1982). Molecular Cloning: A Laboratory Manual. Cold Spring Harbor, NY: Cold Spring Harbor Laboratory.

MANN, P. J. G. (1961). Further purification and properties of the amine oxidase of pea seedlings. Biochemical Journal 79, 623-631.

Massay, V., Palmer, G. \& Bennett, R. (1961). The purification and properties of D-amino acid oxidase. Biochimica et Biophysica Acta 48, $1-9$.

Messing, J. (1983). New M13 vectors for cloning. Methods in Enzymology 101, 20-78.

Miller, J. H. (1972). Experiments in Molecular Genetics. Cold Spring Harbor, NY: Cold Spring Harbor Laboratory.

Mondovi, B., Rotilio, G., Finazzi, A. \& Scioscia-Santoro, A. (1964). Purification of pig kidney diamine oxidase and its identity with histaminase. Biochemical Journal 91, 408-415.

ROSENBERG, M. \& COURT, D. (1979). Regulatory sequences involved in promotion and termination of RNA transcription. Annual Review of Genetics 13, 319-353.

Russell, D. H., Levy, C. C., SchimpfF, S. C. \& HaWk, I. A. (1971). Urinary polyamines in cancer patients. Cancer Research 31, $1555-1558$.

SaIto, H. \& MiUra, K. (1963). Preparation of transforming deoxyribonucleic acid by phenol treatment. Biochimica et Biophysica Acta 72, 619-629.

SANGER, F., Nicklen, S. \& Coulson, A. R. (1977). DNA sequencing with chain-terminating inhibitors. Proceedings of the National Academy of Sciences of the United States of America 74, 5463-5467.

SCHein, C. H. \& NoteboRN, M. H. M. (1988). Formation of soluble recombinant proteins in Escherichia coli is favored by lower growth temperature. Bio/Technology 6, 291-294.

Scrutton, N. S., Berry, A. \& Perham, R. N. (1990. Redesign of coenzyme specificity of a dehydrogenase by protein engineering. Nature, London 343, 38-43.

ShePard, H. M., Yelverton, E. \& Goeddel, D. V. (1982). Increased synthesis in E. coli of fibloblast and leukocyte interferons through alterations in ribosome binding site. DNA 1, 125-131.

Shine, J. \& Dalgarno, L. (1974). The 3'-terminal sequence of E. coli 16S ribosomal RNA: complementarity to nonsense triplets and ribosome binding sites. Proceedings of the National Academy of Sciences of the United States of America 71, 1342-1346.

SOUTHERN, E. M. (1975). Detection of specific sequences among DNA fragments separated by gel electrophoresis. Journal of Molecular Biology 98, 503-517.

SwOBODA, B. E. P. \& Massay, V. (1965). Purification and properties of the glucose oxidase from Aspergillus niger. Journal of Biological Chemistry 240, 2209-2215.

TABOR, H. (1951). Diamine oxidase. Journal of Biological Chemistry 188, 125-136.

TAKami, H., Romsdahl, M. M. \& Nishioka, K. (1979). Polyamines in blood-cells as a cancer marker. Lancet ii, 912 .

Wellner, D. \& MeISTER, A. (1961). Studies on the mechanism of action of L-amino acid oxidase. Journal of Biological Chemistry 236, 2357-2364

Wierenga, R. K., De Maeyer, M. C. H. \& Hol, W. G. J. (1985). Interaction of pyrophosphate moieties with $\alpha$-helixes in dinucleotide binding proteins. Biochemistry 24, 1346-1357.

Yamada, H., Adachi, O. \& Ogata, K. (1965a). Putrescine oxidase, a diamine oxidase requiring flavin adenine dinucleotide. Agricultural and Biological Chemistry 29, 1148-1149.

Yamada, H., Tanaka, A. \& Ogata, K. (1965b). Putrescine oxidase of Micrococcus rubens. Agricultural and Biological Chemistry 29, 260-261.

Yanisch-Perron, C., Vieira, J. \& Messing, J. (1985). Improved M13 phage cloning vectors and host strains: nucleotide sequences of the M13mp18 and pUC19 vectors. Gene 33, 103-109. 